\title{
GAMBARAN FAKTOR LETAK GEOGRAFIS DAN KUNJUNGAN POSYANDU PASIRPARI DI WILAYAH KERJA PUSKESMAS CIAWI TAHUN 2012.
}

Oleh:

\author{
lilis lisnawati, SST, M.Keb
}

\section{A. Abstrak}

Berdasarkan sumber data yang dilihat di Puskesmas Ciawi diperoleh bahwa jumlah kader Posyandu sebanyak 315 orang yang tersebar di 76 posyandu (tiap posyandu memiliki 2-6 orang kader). Pencapaian target D/S (jumlah bayi dan anak Balita yang datang dan ditimbang di Posyandu dibanding dengan semua bayi dan anak Balita yang ada) sebesar 72,01\%. Salah satu desa di Kecamatan Ciawi adalah Desa Pasirhuni dengan wilayah kerja sebanyak $14 \mathrm{RW}$ yang memiliki 10 posyandu, yang dibina oleh 1 orang petugas (bidan desa) dan di bantu oleh 43 kader. Peran serta ibu yang mempunyai balita dalam kegiatan posyandu masih kurang, hal ini dapat dilihat dari sejumlah balita yang ada sebanyak 84 orang, sebesar 60\% ibu balita yang datang ke Posyandu untuk menimbangkan balitanya. Tujuan Mengetahui gambaran faktor yang berhubungan dengan kunjungan Posyandu Pasirpari di wilayah kerja Puskesmas Ciawi tahun 2012.

Jenis penelitian ini termasuk kuantitatif dengan menggunakan metode deskriptif. Populasi dalam penelitian ini adalah semua ibu balita usia 0-5 tahun di Posyandu Pasripari Kecamatan Ciawi pada bulan Maret tahun 2012 yang berjumlah 84 orang.Pengambilan sampel dalam penelitian ini adalah menggunakan teknik purposive sampling Setelah dilakukan penelitian jumlah sampel berdasarkan kriteria tersebut sebanyak 76 orang.Instrument penelitian adalah format kuesioner yang telah dibuat sendiri oleh peneliti. Analisis data yang digunakan adalalah analisis univariat untuk menganalisis variabel Letak geografis, dan kunjungan ke posyandu melalui distribusi frekuensi.

Hasil penelitian didapatkan bahwa Letak Geografis Distribusi faktor letak geografis yang berhubungan dengan kunjungan ke Posyandu Pasirpari di wilayah kerja Puskesmas Ciawi tahun 2012 menunjukkan bahwa letak geografis/ keterjangkauan kke Posyandu paling banyak termasuk dekat yaitu 65 orang (85,5\%), dan yang jauh sebanyak 11 orang (14,5\%). Data menunjukkan bahwa sebagian besar responden tidak teratur dalam kunjungan Posyandu yaitu 43 orang (56,6\%), dan teratur 33 orang (43,3\%).

Simpulan dari penelitian ini adalah letak geografis atau keterjangkauan ke posyandu paling banyak termasuk dekat yaitu 65 orang (85,5\%), dan yang jauh sebanyak 11 orang $(14,5 \%)$ serta data kunjungan sebagian responden tidak teratur dalam kunjungan posyandu yaitu 43 orang (56,6\%), dan teratur 33 orang (43,3\%). Saran yang direkomendasikan adalah bagi aparatur pemerintahan bekerjasama dengan pihak puskesmas dalam menyusun kegiatan pokjanal poyandu serta menentukan lokasi posyandu yang dapat terjangkau oleh seluruh masyarakat sehingga pelayanan dasar posyandu dapat terjangkau oleh seluruh masyarakat.

Kata Kunci: Letak geografis, Kunjungan ke posyandu 


\section{B. Latar belakang}

Tujuan pembangunan kesehatan adalah tercapainya kemampuan hidup sehat bagi setiap penduduk atau individu agar dapat mewujudkan derajat kesehatan masyarakat yang optimal. Posyandu merupakan salah satu bentuk kesehatan bersumber daya manusia guna memberdayakan masyarakat dalam memperoleh pelayanan kesehatan dasar, utamanya untuk mempercepat penurunan angka kematian ibu dan bayi (Zulkifli, 2009).

Menurut hasil survei demografi Kesehatan Indonesia (SDKI) Angka kematian bayi (AKB) di indonesia pada tahun 2007 mencapai $34 / 1000$ kelahiran hidup dan angka kematian ibu (AKI) mencapai kisaran 228/100.0000 kelahiran hidup (SDKI, 2007). Data tersebut menunjukkan masih rendahnya status kesehatan ibu dan bayi baru lahir, rendahnya akses dan kualitas pelayanan kesehatan ibu dan anak khususnya pada masa persalinan dan segera sesudahnya, serta perilaku (baik yang bersifat preventif maupun kuratif) ibu hamil dan keluarga serta masyarakat yang bersifat negatif bagi perkembangan kehamilan sehat, persalinan yang aman dan perkembangan dini anak (SDKI, 2010)

Upaya yang dilakukan baik yang bersifat preventif maupun kuratif adalah posyandu yang merupakan tempat atau media yang paling dekat dengan masyarakat dalam pemantauan gizi pada balita. Pos pelayanan terpadu inimerupakan wadah titik temu antara pelayanan profesional dari petugas kesehatan dan peran serta masyarakat. Partisipasi masyarakat dalam kegiatan Posyandu merupakan proses keadaan ketika individu, keluarga maupun masyarakat umum ikut serta bertanggung jawab terhadap kesehatan keluarga atau kesehatan masyarakat lingkungannya. Namun berbagai hambatan dalam memelihara kesehatan diri dan keluarganya perlu mendapatkan perhatian (Hendarji, 2010). Sebagai indikator pencapaian dalam program Posyandu yang yang kekuatannya terletak pada pelayanan kesehatan dasar, kerjasama lintas sektoral dan peran serta masyarakat.

Berdasarkan sumber data yang dilihat di Puskesmas Ciawi diperoleh bahwa jumlah kader Posyandu sebanyak 315 orang yang tersebar di 76 posyandu (tiap posyandu memiliki 2-6 orang kader). Pencapaian target D/S (jumlah bayi dan anak Balita yang datang dan ditimbang di Posyandu dibanding dengan semua bayi dan anak Balita yang ada) sebesar 72,01\%. Salah satu desa di Kecamatan Ciawi adalah Desa Pasirhuni dengan wilayah kerja sebanyak 14 RW yang memiliki 10 posyandu, yang dibina oleh 1 orang petugas (bidan desa) dan di bantu oleh 43 kader.

Peran serta ibu yang mempunyai balita dalam kegiatan Posyandu masih kurang, hal ini dapat dilihat dari jumlah balita yang ada sebanyak 84 orang, sebesar $60 \%$ ibu balita yang datang ke Posyandu untuk menimbangkan balitanya. Kunjungan ibu balita ke Posyandu erat kaitannya dengan perilaku kesehatan, perilaku kesehatan hakikatnya adalah halhal yang berkaitan dengan tindakan atau kegiatan ibu dalam memelihara dan meningkatkan kesehatan balitanya. Kesehatan seseorang dipengaruhi atau terbentuk dari beberapa faktor. Green menjelaskan bahwa perilaku itu dilatar belakangi atau dipengaruhi oleh tiga faktor pokok yaitu faktor predisposisi (predisposing factors), faktor pendukung (enabling factors) dan faktor pendorong (reinforcing factors).

Berdasarkan uraian diatas maka penulis bermaksud melakukan penelitian mengenai gambaran faktor yang berhubungan dengan kunjungan posyandu pasirpari di wilayah kerja Puskesmas Ciawi Tahun 2012. 


\section{Metode}

Jenis penelitian ini termasuk kuantitatif dengan menggunakan metode deskriptif. Populasi dalam penelitian ini adalah semua ibu balita usia 0-5 tahun di Posyandu Pasripari Kecamatan Ciawi pada bulan Maret tahun 2012 yang berjumlah 84 orang. Pengambilan sampel dalam penelitian ini adalah menggunakan teknik purposive sampling Setelah dilakukan penelitian jumlah sampel berdasarkan kriteria tersebut sebanyak 76 orang.

Instrument penelitian adalah format kuesioner yang telah dibuat sendiri oleh peneliti. Tahap Pengolahan Data meliputi Data yang telah ada diolah dan dianalisis dengan melalui tahap :

1. Editing Data, yaitu pemeriksaan kuesioner, apakah masih ada yang kurang lengkap atau ada jawaban atau

\section{Hasil penelitian}

1. Letak Geografis Distribusi factor letak geografis yang berhubungan dengan kunjungan ke Posyandu Pasirpari di wilayah kerja Puskesmas Ciawi tahun 2012 menunjukkan bahwa letak geografis/ keterjangkauan kke Posyandu paling banyak termasuk

\section{E. Pembahasan}

Hasil penelitian menunjukkan bahwa letak geografis/ keterjangkauan ke Posyandu paling banyak termasuk dekat $(85,5 \%)$. Disini terlihat

Posyandu, namun keberadaan ini tidak dimanfaatkan oleh ibu balita. Hasil penelitian berbeda dengan teori Azwar (2004) yang mengatakan bahwa syarat pokok pelayanan kesehatan yang baik adalah yang mudah di

capai oleh masyarakat. Pengertian ketercapaian yang di maksud di sini terutama dari sudut lokasi. Demikian untuk dapat mewujudkan pelayanan kesehatan yang baik, maka pengaturan disrtibusi sarana kesehatan menjadi sangat penting. data yang kurang konsisten

2. Coding Data, yaitu melakukan pengkodean atau pemberian kode terhadap tiap variabel.

3. Scoring

Pemberian skor untuk variabel pengetahuan bila benar diberi skor 1 dan bila salah diber skor 0 , dan variabel dukungan suami diberi skor 1 apabila Ya, skor 0 apabila Tidak.

4. Tabulating Data, yaitu melakukan pengolahan data berdasarkan hasil kuesioner.

5. Entry Data, yaitu memasukan data ke dalam komputer.

Analisis data yang digunakan adalalah analisis univariat untuk menganalisis variabel Letak geografis, dan kunjungan ke posyandu melalui distribusi frekuensi.

dekat yaitu 65 orang $(85,5 \%)$, dan yang jauh sebanyak 11 orang $(14,5 \%)$.

2. Keteraturan Kunjungan posyandu

Data menunjukkan bahwa sebagian besar responden tidak teratur dalam kunjungan Posyandu yaitu 43 orang $(56,6 \%)$, dan teratur 33 orang $(43,3 \%)$.

kontradiksi, apabilia dilihat dari keterjangkauan, maka jarak dari rumah responden ke Posyandu memudahkan ibu balita untuk selalu berkunjung ke

Pernyataan tersebut didukung oleh pernyataan Notoatmodjo (2007) yang mengungkapkan bahwa rendahnya status kesehatan penduduk miskin terutama di sebabkan oleh terbatasnya askes terhadap pelayanan kesehatan, karena kendala geografis dan kendala biaya, latarbelakang sosial, sruktur sosial dan ekonomi mempunyai pengaruh terhadap perilaku masyarakat.

Mereka lebih mencari pengobatan ke fasilitas-fasilitas pengobatan tradisional (traditional remedy). Identik dengan 
pencarian pengobatanpun lebih berorientasi ke sosial budaya.

Hasil penelitian diperoleh sebagian besar responden tidak teratur dalam kunjungan Posyandu yaitu 43 orang $(56,6 \%)$, dan teratur 33 orang $(43,3 \%)$. Data tersebut menunjukkan bahwa sebagian besar responden tidak memanfaatkan keberadaan Posyandu. Padahal Posyandu merupakan salah satu wahana kegiatan masyarakat untuk mendeteksi kesehatan balita sebagai salah satu sasaran kegiatan Posyandi tersebut.

Menurut Azwar (2004) Posyandu merupakan pusat kegiatan masyarakat dibidang Keluarga Berencana dan kesehatan yang dapat dikembangkan berdasarkan pendekatan yang kekuatannya terletak pada pelayanan kesehatan dasar, kerjasama lintas

\section{F. Simpulan dan saran}

Simpulan dari penelitian ini adalah letak geografis/ keterjangkauan kke Posyandu paling banyak termasuk dekat yaitu 65 orang $(85,5 \%)$, dan yang jauh sebanyak 11 orang $(14,5 \%)$ serta data kunjungan sebagian besar responden tidak teratur dalam kunjungan Posyandu yaitu 43 orang $(56,6 \%)$, dan teratur 33 orang $(43,3 \%)$.

\section{G. Referensi}

Azwar. (2004). Pengantar Administrasi Kesehatan, Edisi ketiga, Binarupa Aksara, Jakarta, Hal 37.

BKKBN. (2004). Kesehatan Nasional, Jakarta, http://www.depkes.go.id tanggal 15 Maret 2012

Depkes RI. (2006). Posyandu, http://www.depkes.go.id Diperoleh tanggal 1Maret 2012.

Geynor. (2007). Disebabkan Kelalain Suami, Kematian ibu Masih Tinggi, Tersedia

Notoatmodjo. (2007). Ilmu Kesehatan Masyarakat: Teori dan Aplikasi, Rhineka sektoral dan peran serta masyarakat. Posyandu sebagai wahana alih informasi dan teknologi dari petugas kesehatan kepada masyarakat, pada masa krisis ekonomi keberadaannya kurang menggembirakan.

Identik dengan itu, adanya data lapangan tentang tingkat partisipasi masyarakat dalam pelayanan kesehatan di Posyandu dan desa menunjukkan angka cakupan kunjungan Posyandu masih rendah Menurut Teori Green dalamNotoatmodjo (2010) berpendapat, bahwa tingkah laku manusia banyak didasarkan untuk mencapai sesuatu tujuan. Perilaku masyarakat dalam program kesehatan dipengaruhi oleh 3 faktor, yaitu predisposing factors (faktor penentu), enabling factors (faktor pemungkin), dan reinforcing factors (faktor pendorong).

Saran yang direkomendasikan adalah bagi aparatur pemerintahan bekerjasama dengan pihak puskesmas dalam menyusun kegiatan pokjanal posyandu serta menentukan lokasi posyandu yang dapat terjangkau oleh seluruh masyarakat sehingga pelayanan dasar posyandu dapat terjangkau oleh seluruh masyarakat.

Cipta, Jakarta,Hal 78

Sudayasa. (2009). 11 Indikator Dasar Pelayanan Kesehatan Ibu Dan Anak: isadur

Syakira, G. (2009). Tentang Posyandu, http://sykue-blog.blogspot.com.

Diperoleh tanggal 30 Maret 2012

Winarsih.

Tasikmalaya Tahun 2009. Tidak di Publikasikan.

Zulkifli.(2005). Pedoman umum pengelolaan posyandu, http://ww.depkes.go.id. Diperoledhari : http://ww tanggal 1 Maret 2012 